Task 6 - Subtask 1: PNNL Visit by JAEA Researchers to Evaluate the Feasibility of the FLESCOT Code for the Future JAEA Use for the Fukushima Surface Water Environmental Assessment

Y Onishi

January 2014

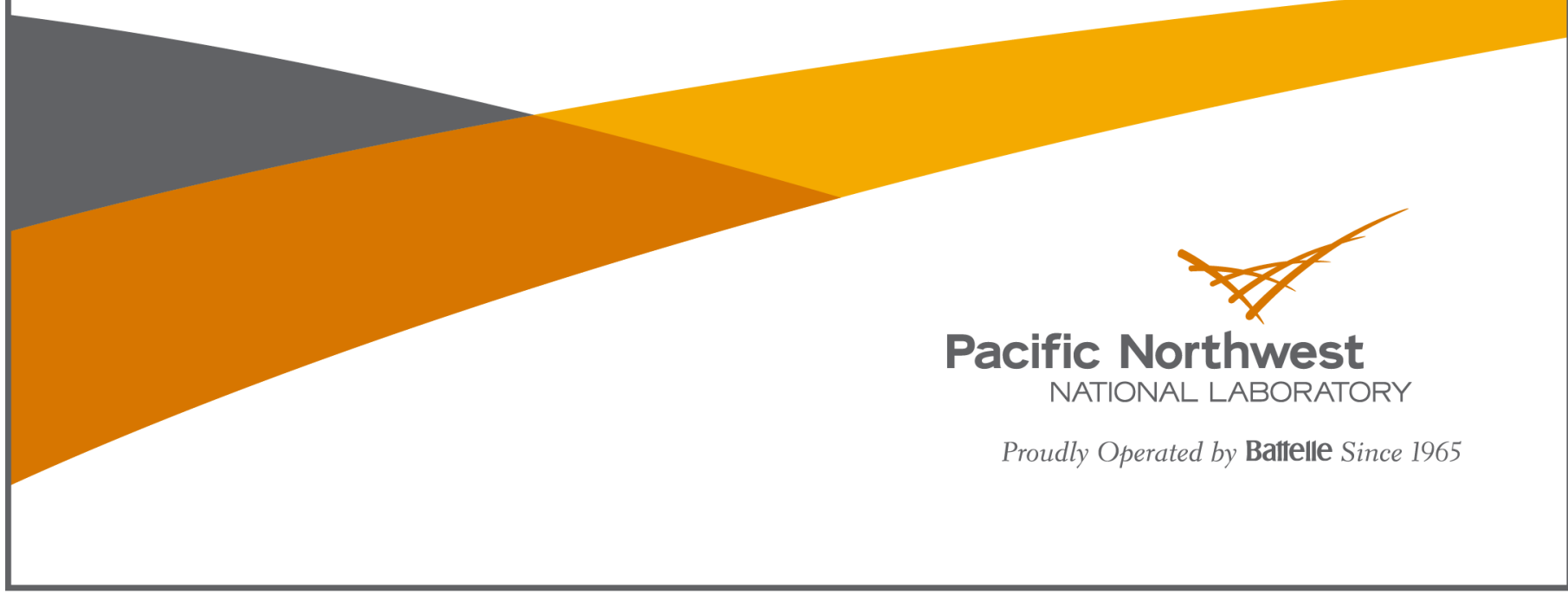




\title{
DISCLAIMER
}

This report was prepared as an account of work sponsored by an agency of the United States Government. Neither the United States Government nor any agency thereof, nor Battelle Memorial Institute, nor any of their employees, makes any warranty, express or implied, or assumes any legal liability or responsibility for the accuracy, completeness, or usefulness of any information, apparatus, product, or process disclosed, or represents that its use would not infringe privately owned rights. Reference herein to any specific commercial product, process, or service by trade name, trademark, manufacturer, or otherwise does not necessarily constitute or imply its endorsement, recommendation, or favoring by the United States Government or any agency thereof, or Battelle Memorial Institute. The views and opinions of authors expressed herein do not necessarily state or reflect those of the United States Government or any agency thereof.

\author{
PACIFIC NORTHWEST NATIONAL LABORATORY \\ operated by \\ BATTELLE \\ for the \\ UNITED STATES DEPARTMENT OF ENERGY \\ under Contract DE-AC05-76RL01830
}

Printed in the United States of America
Available to DOE and DOE contractors from the Office of Scientific and Technical Information,
P.O. Box 62, Oak Ridge, TN 37831-0062;
ph: (865) 576-8401
fax: $(865)$ 576-5728
email: reports@adonis.osti.gov

\begin{abstract}
Available to the public from the National Technical Information Service, U.S. Department of Commerce, 5285 Port Royal Rd., Springfield, VA 22161 ph: (800) 553-6847 fax: $(703) 605-6900$ email: orders@ntis.fedworld.gov online ordering: http://www.ntis.gov/ordering.htm
\end{abstract}

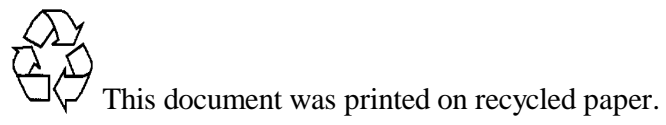




\section{Task 6 - Subtask 1: PNNL Visit by JAEA Researchers to Evaluate the Feasibility of the FLESCOT Code for the Future JAEA Use for the Fukushima Surface Water Environmental Assessment}

Y Onishi

January 2014

Prepared for

the Japan Atomic Energy Agency under Contract 61537 


\section{概要}

日本原子力機構（JAEA）より研究者 4 名 (町田氏、山田氏、奥村氏、北村氏) が平日 7 日 のあいだ米国エネルギー省のパシフィックノースウエスト国立研究 (PNNL)を訪問した。訪問中 に JAEA の研究者は PNNL が開発した 3 次元河川・河口・沿岸域シミュレーションコード FLESCOT (Flow, Energy, Salinity, Sediment and Contaminant Transport) を PNNL のコンピュータで 実際に使用する事ができ、PNNL の援助の基に JAEA の研究者が大規模に FLESCOT コードを並列 化できる可能性、そして並列化した FLESCOT コードが JAEA の所有するスーパーコンピュータ の機能力に適合・適応しているかを自ら評価し検討した。FLESCOT コードの評価・検討に加えて

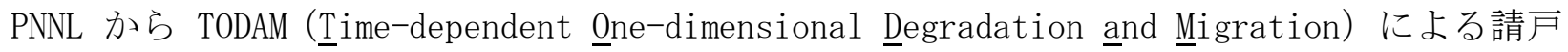
川モデルの現状報告があり、今後のモデル方針の検討がなされた。それに JAEA と PNNLL の環境 分子科学研究所 (Environmental Molecular Science Laboratory-EMSL) との共同研究の可能性も 検討した。

PNNL の環境分子科学研究所 (Environmental Molecular Science Laboratory)訪問では、 JAEA はPNNL のスーパーコンピュータやPNNL の環境分子科学研究所に関する研究や研究設備 を見学した。

JAEA の PNNL 訪問は下記にまとめられる。

TODAM による解析の状況について

・請戸川に大柿ダムおよび合流する河川群を付加したモデルを構築した。

・ F-TRACE の調査分析結果がまだ不足しているため、MAP 事業等の数值で未知のパラメータ をある程度推測した計算を進めた。

・ 大柿ダム上流の污染度合いが高く、その水が下流に流れていくため、TODAMを污染移行対 策等の検討に活用するには、上流側の河川の実測值が必要である。

・ 今後の予定として、これまでの成果と TODAM の数理的側面を 3 月までに PNNLのドキュ メントにまとめる。

・また、調査結果を反映できるようになった段階で論文誌原稿にまとめることとした。

FLESCOT による荻ダムのモデル化について（PNNL と JAEAの共同研究）

・調査チームより提供された荻ダムの測量データを用いて、FLESCOT 用のインプットデータ を作成した。

・ 実測值の流入量があまりにも小さいため、テスト計算ではその 10 倍の值を設定して解析を 進めた。

・ 現状では一時間の現象を計算するのに 17 分を要した。ダム底への浮遊砂等の堆積状況を捉 えるためには一年程度の計算が必要となるため、少なくとも 100 倍程度の並列化が望まれ る。

・ 少なくとも簡単な計算は確認でき、今後の展開として大柿ダムや場合によっては福島原発河 口域の計算にも応用できる可能性があるが、まずは調査の進んでいる荻ダムの計算を推進 することとした。 
FLESCOT のコードについて（JAEA の考察）

・ FLESCOT コードは dynamic pressure と hydrostatic pressure（静水圧）でシミュレーションで きるが、海洋の流動解析モデルとして、通常の場合は静水圧近似を採用していることを確 認。

・ 潮位の変動モデルについては、局所的な沿岸域を対象とする場合、全域にて潮位変動によ る水深変動を与えることを確認した。

・ 堆積層のモデルは、TODAM と全く同一である一方、FLESCOT は、海底 2 次元格子上で上 記モデルを適用していることを確認した。

・ 堆積層のモデルにて、縦方向の拡散と bioturbationの効果か考慮出来る事を確認した。

・ 今回 FLESCOT のコードは閲覧のみ可で、コピー等は禁止されたため、細部にわたって習得 することは適わなかったが、主要点については習得することができた。

FLESCOT の並列化について（JAEA の考察）

・PNNL の大西氏と Eyler 氏が 3 次元流体シミュレーションコード FLESCOT の主要ルーチン の機能について説明した。

・PNNLの Glass 氏より FLESCOT の計算量の多いルーチンについての説明があった。

・ いくつかの解析対象問題に対して FLESCOT でどのサブルーチンが時間を要するかを調べた。 その結果、圧力場を計算するサブルーチン、SPECTR という浮遊砂の移行を計算するサブル 一チン、および流体計算のうち質量の整合性を計算するところであることが判明した。た だし、これらの事項は解析対象が何であるかによって変わりうるので注意が必要である。

- 浮遊砂の移行計算では、砂・シルト・粘土・溶存放射性物質・砂に付着した放射性物質・シ ルトに付着した放射性物質・粘土に付着した放射性物質・塩の都合 8 つ濃度を計算する 部位は独立にできるので、少なくともこの部分の並列化は容易にできる。

- FLESCOT は TODAM と異なり浮遊砂・堆積砂・再浮遊砂・川底砂についてそれぞれ独立に $\mathrm{Kd}$ を設定できるようにしている。ここも並列可能である。

・ 上記の情報を基に、JAEA 研究者が計算量の多いルーチンの並列化を行った。PNNLへの滞 在時間を考慮し、通信を最適化した本格的な並列化ではなく、通信量が多い簡単な並列化 を行った。

・実際に並列計算機で計算時間を測定したところ、10\%程度ではあるが並列化による高速化 が確認できた。今後、JAEAに持ち帰り検討し、必要に応じて短期滞在により PNNLにて並 列化を推進していくこととした。

・PNNL と JAEA は PNNL 大西氏および Eyler 氏も含め FLESCOT の並列化の可能性の議論を 行った。並列化の可能性は肯定的であるという意見がでた。

・なお、FLESCOT に必要な修正をPNNL 側で行うこととした。大西氏としては来年の夏ごろ に両者である程度使えるめどが立った段階で機構側に FLESCOT 導入することを考えてい るとのこと。

EMSL との共同研究に関する打ち合わせ結果について

- JAEA 研究者から、JAEA での分子モデリング研究の進捗状況を発表。研究内容について質 疑応答、議論。

・ PNNLの Felmy 氏から JAEA との共同研究について、「除去土壌の減容化の技術開発などの 工学的な目標を実現させるのではなく、そのために必要な科学的な知見を解明する研究を 行う分野で、協力可能であり、是非共同研究を行いたい」という方針である事を伝えた。 
・ 今後の共同研究に向けて、次の 4 つの研究課題の提案をPNNL は提出した。

1. 粘土鉱物の電荷構造がセシウム吸着能力に及ぼす影響に関する研究

2. 粘土鉱物の表面やエッジへのセシウム脱着における酸の影響に関する研究

3. 粘土鉱物のセシウム吸着現象における水和効果に関する研究

4. 粘土鉱物のほつれたエッジ吸着サイトにおける層間膨張効果に関寸る研究

- JAEA は PNNL からの提案の 2 番目「粘土鉱物の表面やエッジへのセシウム脱着における酸 の影響に関する研究」を主な研究課題として共同研究を進める事を希望する旨を伝えた。

・PNNL 加共同研究を進める場合、予算について以下の 2 項目を伝えられる。

1. PNNL の計算機環境については、以下の方法があり、いずれも無料である事が伝えられ た。

i. 提案書を出して使用許可をもらう

ii. Felmy 氏が使用を許可されている計算機を用いる

2. PNNL の計算科学チームでは、現在、セシウム吸脱着関連の予算が無いため、研究に必 要な人件費についてはJAEAが負担する必要がある。

・ JAEA からは、JAEA 研究者のPNNL の留学の可能性も含めて検討する旨を返答した。

・後に、大西氏は、もし新たな JAEA 研究者が留学寸る場合には、分子モデリングだけでなく、 FLESCOT のシミュレーションについても行う事を提案した。

土壌侵食およびセシウム移行モデルの原稿内容の改良について（JAEA）

- JAEA 側で中心に進めている森林を含めた福島の地表に沈着したセシウムの将来分布予測解 析について、土地利用別・河川およびダム流域別に整理・評価した原稿についてのコメン 卜を大西氏に要求した。

・5 日ほどかけて大西氏はコメントを出し、改善ポイントが整理された。JAEA は今後修正を 行い11月中にまとめ直すこととした。 


\section{Contents}

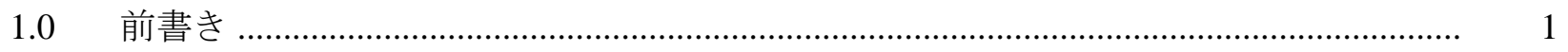

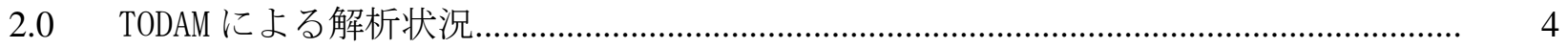

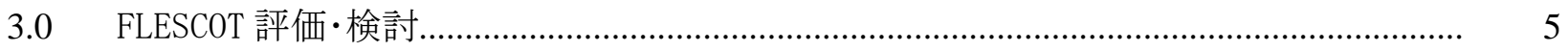

$3.1 \quad$ FLESCOT による荻ダムのモデル化（PNNL と JAEA） ….............................................. 5

3.2 FLESCOT コード (JAEA） _.................................................................................. 5

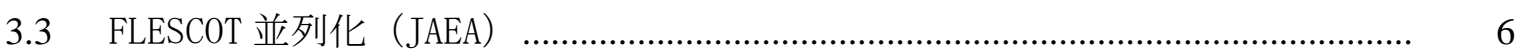

4.0 EMSL との共同研究検討とその他の実行項目 ………………………………........................ 7

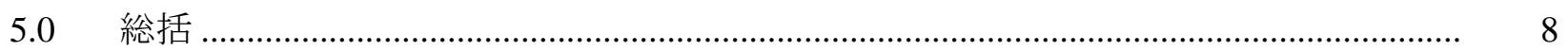

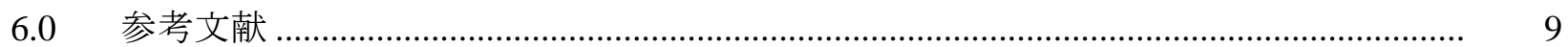




\section{0 前書き}

日本原子力機構（JAEA）より研究者 4 名 (町田氏、山田氏、奥村氏、北村氏) が平日 7 日 のあいだ米国エネルギー省のパシフィックノースウエスト国立研究（PNNL）を訪問した。訪問の 主要目的は PNNL が開発した 3 次元河川・河口・沿岸域シミュレーションコード FLESCOT (F1ow, Energy, Salinity, Sediment and Contaminant Transport) (Onishi et al. 1992, 1993) が JAEA の所有するスーパーコンピュータに対して適合するか、もしくは適応できるかを評価し検 討することであった。FLESCOT コードを並列化して福島県にあるダム貯水所・河口・沿岸域に おいての放射性セシウムの移行をより効果的に JAEA のスーパーコンピュータでシミュレーショ ンするためである。

PNNL は FLESCOT コードについて下記の項目をJAEA に提供した。

- FLESCOT source code

- User's manual

- FLESCOT description

$\begin{array}{ll}\circ & \text { Program structure } \\ \circ & \text { Algorism } \\ \circ & \text { Solver } \\ \circ & \text { Boundary condition handling } \\ \circ & \text { Data definition } \\ \circ & \text { Input and output methods } \\ \circ & \text { How to run. }\end{array}$

PNNL は JAEA の研究者が污染物の移行をシミュレーションするための標本となる FLESCOT コードへの情報入カファイルを作製し、それをもって JAEA の研究者は訪問中に PNNL のコンピュータで実際に FLESCOT コードを使用した。実際に FLESCOT コードを使用することに より JAEA の研究者は大規模に FLESCOT コードを並列化できる可能性、そして並列化した FLESCOT コードが JAEA のスーパーコンピュータの機能力に適合・適応しているかを自ら評価し 検討することが出来た。JAEA による FLESCOT コードの評価・検討の内容は以下の章に説明され る。

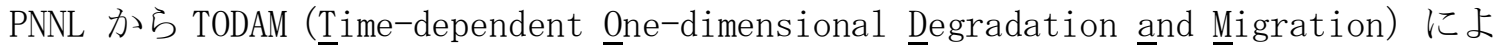
る請戸川モデルの現状報告をし、今後のモデル方針の検討をした。検討内容は以下の章に説明 する。

JAEA と PNNLL の環境分子科学研究所 (Environmental Molecular Science LaboratoryEMSL) との共同研究の可能性が検討された。検討内容は以下の章に説明される。

JAEA の PNN 訪問時の agenda は表 1 に示す。 
表 1.JAEA の PNN 訪問時の agenda

Thursday, (10/31/2013)

$\begin{array}{lll}\text { TIME } & \text { TOPIC } & \text { LOCATION } \\ 9: 15 \mathrm{am} & \text { ETB Badge Office } & \begin{array}{l}\text { ETB } \\ \text { Yasuo Onishi }\end{array} \\ 10: 00-12: 00 \mathrm{am} & \text { FLESCOT Introduction } & \begin{array}{l}\text { ISB1/115 } \\ \text { Yasuo Onishi }\end{array} \\ 12: 00-1: 00 \mathrm{pm} & \text { Lunch } & \\ 1: 00-5: 00 \mathrm{pm} & \text { TODAM Review } & \begin{array}{l}\text { ISB1/115 } \\ \text { FLESCOT Description }\end{array} \\ & \text { Fasuo Onishi }\end{array}$

Friday, (11/01/2013)

10:00 - 12:00 pm

Molecular Modeling

ISB1/115

Presentation by Okumura

Okumura

Andy Felmy

12:00 - 1:00 pm Lunch

$1: 00-3: 00 \mathrm{pm}$

Molecular Modeling Discussion

ISB1/115

Andy Felmy

Okumura

$3: 00-5: 00 \mathrm{pm}$

EMSL Tour

EMSL

Dave Koppenaal

Monday (11/04/2013)

10:00 - 12:00 am

FLESCOT Survey

ISB1/234

Yasuo Onishi

L. Loren Eyler

$12: 00-1: 00 \mathrm{pm}$

Lunch

$1: 00-5: 00 \mathrm{pm}$

FLESCOT Survey

ISB1 $/ 234$

Yasuo Onishi

L. Loren Eyler

Tuesday (11/05/2013)

10:00 - 12:00 am

FLESCOT Survey

ISB1/115

Yasuo Onishi

L. Loren Eyler

$12: 00-1: 00 \mathrm{pm}$

Lunch 
$1: 00-3: 00 \mathrm{pm}$

$3: 00-5: 00 \mathrm{pm}$

Wednesday (11/06/2013)
PNNLParallel Computing

Capabilities

FLESCOT Survey

FLESCOT Survey

10:00 - 12:00 am

$12: 00-1: 00 \mathrm{pm}$

1:00 - 5:00 pm

Thursday $(11 / 07 / 2013)$

10:00 - 12:00 am

FLESCOT Survey

Lunch

FLESCOT Survey
ISB1/115

Kevin Glass

ISB1/115

Yasuo Onishi

L. Loren Eyler
ISB1 $/ 234$

Yasuo Onishi

L. Loren Eyler

ISB1/234

Yasuo Onishi

L. Loren Eyler
ISB1 $/ 234$

Yasuo Onishi

L. Loren Eyler

ISB1 $/ 234$

Yasuo Onishi

L. Loren Eyler

Friday $(11 / 08 / 2013)$

10:00 - 12:00 am

FLESCOT Survey

ISB $1 / 234$

Yasuo Onishi

L. Loren Eyler

$12: 00-1: 00 \mathrm{pm}$

Lunch

$1: 00-5: 00 \mathrm{pm}$

Wrap Up and Path Forward

ISB1/234

Yasuo Onishi

5:00 pm

Ad journ 


\subsection{TODAM による解析状況}

PNNL 参加者：大西氏、Yokuda 氏、Eyler 氏、Glass 氏

JAEA 参加者：町田氏、山田氏、奥村氏、北村氏、操上氏

TODAM による請戸川モデルの現状報告と今後のモデル方針を下記に記す。

・＼cjkstart請戸川に大柿ダムおよび合流する河川群を付加したモデルを構築した。

・ F-TRACE の調査分析結果がまだ不足しているため、MAP 事業等の数值で未知のパラメータを ある程度推測した計算を進めた。

・ 大柿ダム上流の污染度合いが高く、その水が下流に流れていくため、TODAM を污染移行対 策等の検討に活用するには、上流側の河川の実測值が必要である。

・ 今後の予定として、これまでの成果と TODAM の数理的側面を 3 月までに PNNL のドキュメン トにまとめる。

・調査結果を反映できるようになった段階で論文誌原稿にまとめることとした。 


\subsection{FLESCOT 評価・検討}

PNNL 参加者：大西先生、Yokuda 氏、Eyler 氏、Glass 氏 JAEA 参加者： 町田、山田、奥村、北村、操上

JAEA による FLESCOT の評価・検討の為、PNNL は FLESCOT のプログラムコード、プログラム 構成の説明、コードの使用マニュアルを提供した。それに加えて、FLESCOT シミュレーション においての主要機能についての説明、そして FLESCOT の計算量の多い箇所のルーチンについて の説明をした。下記に FLESCOT 評価・検討を記す。

\section{1ＦLESCOT による荻ダムのモデル化（PNNL と JAEA）}

FLESCOT の評価・検討に使用されるために、FLESCOT による荻ダムのモデルが作られた。モ デルの要点を下記に記す。

・調査チームより提供された荻ダムの測量データを用いて、FLESCOT 用のインプットデータ を作成した。

・ 実測值の流入量があまりにも小さいため、テスト計算ではその 10 倍の值を設定して解析を 進めた。

・ 現状では一時間の現象を計算するのに 17 分を要した。ダム底への浮遊砂等の堆積状況を捉 えるためには一年程度の計算が必要となるため、少なくとも 100 倍程度の並列化が望まれ る。

・ 少なくとも簡単な計算は確認でき、今後の展開として大柿ダムや場合によっては福島原 発河口域の計算にも応用できる可能性があるが、まずは調査の進んでいる荻ダムの計算を 推進することとした。

\subsection{FLESCOT コード（JAEA）}

PNNL は FLESCOT のプログラムコード、プログラム構成の説明、コードの使用マニュアルを 提供した。下記に FLESCOT コードの評価・検討を記す。

・海洋の流動解析モデルとして、通常の場合は静水圧近似を採用していることを確認。

・ 潮位の変動モデルについては、局所的な沿岸域を対象とする場合、全域にて潮位変動によ る水深変動を与えることを確認した。

・ 堆積層のモデルは、TODAM と全く同一である一方、FLESCOT は、海底 2 次元格子上で上記モ デルを適用していることを確認した。

・堆積層のモデルにて、縦方向の拡散と bioturbationの効果か考慮出来る事を確認した。

・ 今回 FLESCOT のコードは閲覧のみ可で、コピー等は禁止されたため、細部にわたって習得 することは適わなかったが、主要点については習得することができた。 


\subsection{FLESCOT 並列化（JAEA）}

大西氏、Eyler 氏から 3 次元流体シミュレーションコード FLESCOT の主要ルーチンの機能に ついての説明、そして PNNL の Glass 氏より FLESCOT の計算量の多い箇所のルーチンについての 説明があった。それ等に基ずいた FLESCOT 並列化の可能性についての評価·検討を下記に記す。

・ いくつかの解析対象問題に対して FLESCOT でどのサブルーチンが時間を要するかを調べた。

・ その結果、圧力場を計算するところ、SPECTR という浮遊砂の移行を計算するところ、およ び流体計算のうち質量の整合性を計算するところであることが判明した。ただし、これら の事項は解析対象が何であるかによって変わりうるので注意が必要である。

・ 浮遊砂の移行計算では、砂・シルト・クレイ・溶存放射性物質・砂に付着した放射性物 質・シルトに付着した放射性物質・クレイに付着した放射性物質・塩の都合 8 つ濃度を 計算する部位は独立にできるので、少なくともこの部分の並列化は容易にできる。

・ また、FLESCOT では TODAM と異なり浮遊砂・堆積砂・再浮遊砂・川底砂についてそれぞれ 独立に Kd を設定できるようにしている。ここも並列可能である。

・ 上記の情報を基に、JAEA 研究者が計算量の多いルーチンの並列化を行った。PNNL への滞在 時間を考慮し、通信を最適化した本格的な並列化ではなく、通信量が多い簡単な並列化を 行った。

・実際に並列計算機で計算時間を測定したところ、10\%程度ではあるが並列化による高速化 が確認できた。今後、JAEA に持ち帰り検討し、必要に応じて短期滞在により PNNLにて並列 化を推進していくこととした。

- PNNL と JAEA は PNNL 大西氏および Eyler 氏も含め FLESCOT の並列化の可能性の議論を 行った。並列化の可能性は肯定的であるという意見がでた。

・ なお、FLESCOT の必要な修正を PNNL 側で行うこととした。大西氏としては来年の夏ごろに 両者である程度使えるめどが立った段階で機構側に FLESCOT を導入することを考えている とのこと。 


\subsection{EMSL との共同研究検討とその他の実行項目}

PNNL 参加者 : Felmy 氏、Chaka 氏、Bylaska 氏、Kerist 氏 JAEA 参加者 : 町田氏、奥村氏、山田氏、北村氏、操上氏

JAEA と PNNLL の環境分子科学研究所 (Environmental Molecular Science Laboratory-EMSL) との共同研究の可能性が検討された。検討内容を下記に記す。

・ JAEA 研究者から、JAEA での分子モデリング研究の進捗状況を発表。研究内容について質疑 応答、議論。

・PNNLの Felmy 氏から JAEA との共同研究について、「除去土壌の減容化の技術開発などの 工学的な目標を実現させるのではなく、そのために必要な科学的な知見を解明する研究を 行う分野で、協力可能であり、是非共同研究を行いたい」という方針である事を伝えた。

・ 今後の共同研究に向けて、PNNL は次の 4 つの研究課題の提案をした。

5. 粘土鉱物の電荷構造がセシウム吸着能力に及ぼす影響に関する研究

6. 粘土鉱物の表面やエッジへのセシウム脱着における酸の影響に関する研究

7. 粘土鉱物のセシウム吸着現象における水和効果に関する研究

8. 粘土鉱物のほつれたエッジ吸着サイトにおける層間膨張効果に関する研究

- JAEA は PNNL からの提案の 2 番目「粘土鉱物の表面やエッジへのセシウム脱着における酸の 影響に関する研究」を主な研究課題として共同研究を進める事を希望する旨を伝えた。

・PNNL から共同研究を進める場合、予算について以下の 2 項目を伝えられる。

3. PNNL の計算機環境については、以下の方法があり、いずれも無料である事が伝えられた。

i. 提案書を出して使用許可をもらう

ii. Felmy 氏が使用を許可されている計算機を用いる

4. PNNL の計算科学チームでは、現在、セシウム吸脱着関連の予算が無いため、研究に必要 な人件費についてはJAEA が負担する必要がある。

・JAEA からは、JAEA 研究者の留学の可能性も含めて検討する旨を返答した。

・後に、大西氏は、もし新たに JAEA 研究者が留学する場合には、分子モデリングだけでなく、 FLESCOT のシミュレーションについても行う事を提案した。

土壤侵食およびセシウム移行モデルの原稿内容の改良について（JAEA）

・ JAEA 側で中心に進めている森林を含めた福島の地表に沈着したセシウムの将来分布予測解 析について、土地利用別・河川およびダム流域別に整理・評価した原稿について大西氏に コメントを要請した。

・5日ほどかけて大西氏はコメントを提出し、改善ポイントが整理された。JAEA は今後修正を 行い 11 月中にまとめ直すこととした。 


\section{0 総括}

日本原子力機構（JAEA）より研究者 4 名が平日 7 日間に渡り米国エネルギー省のパシフィック ノースウエスト国立研究 (PNNL) を訪問した。訪問中に JAEAの研究者は PNNL が開発した 3 次 元河川・河口・沿岸域シミュレーションコードFLESCOT (Flow, Energy, Salinity, Sediment and Contaminant Transport）を PNNL のコンピュータで実際に使用し、PNNL の援助の基に JAEA の研究者が大規模に FLESCOT コードを並列化できる可能性、そして並列化した FLESCOT コードが JAEA の所有するスーパーコンピュータの機能力に適合・適応しているかを自ら評価 し検討した。FLESCOT コードの評価・検討に加えて PNNL から TODAM（Time-dependent Onedimensional Degradation and Migration）による請戸川モデルの現状報告があり、今後のモ デル方針の検討がなされた。それに JAEA と PNNLL の環境分子科学研究所 (Environmenta1 Molecular Science Laboratory-EMSL) との共同研究の可能性も検討した。

TODAM による解析の状況については請戸川に大柿ダムおよび合流する河川群を付加したモデル を構築し、その訪問時での中間結果の発表を行った。

PNNL と JAEA が共同で行っている FLESCOT による荻ダムのモデル化について、

・調査チームより提供された荻ダムの測量データを用いて、FLESCOT 用のインプットデータを作成

・初期のシニュレーションが開始されている状態を説明した。

\section{FLESCOT について}

・ 今回 FLESCOT のコードは閲覧のみ可で、コピー等は禁止されたため、JAEA は FLESCOTを 細部にわたって習得することは適わなかったが、主要点については習得することができた。

・ 福島の河川、ダム湖、太平洋沿岸でのセシウムの移行、蓄積評価の適応性はあると思われ る

- PNNL と JAEA は FLESCOT の並列化の可能性の議論を行った。並列化の可能性は肯定的で あるという意見がでた。

・初期的な結論として FLESCOT をJAEA のスパーコンピュータで使える可能性はあるとおも われる

分子モデリング研究について

・ 共同研究に向けて、次の 4 つの研究課題の提案を PNNLは提出した。

9. 粘土鉱物の電荷構造がセシウム吸着能力に及ぼす影響に関する研究

10. 粘土鉱物の表面やエッジへのセシウム脱着における酸の影響に関する研究

11. 粘土鉱物のセシウム吸着現象における水和効果に関する研究

12. 粘土鉱物のほつれたエッジ吸着サイトにおける層間膨張効果に関する研究

- JAEA は PNNL からの提案の 2 番目「粘土鉱物の表面やエッジへのセシウム脱着における酸 の影響に関する研究」を主な研究課題として共同研究を進める事を希望する旨を伝えた。

JAEA 研究者のPNNLへの留学の可能性も吟味された。 


\section{0 参考文献}

Onishi Y, HC Graber, and DS Trent. 1993. "Preliminary Modeling of Wave-Enhanced Sediment and Contaminant Transport in New Bedford Harbor." In Book Series 42 of Estuarine and Coastal Water Cohesive Sediment Transport, AJ Mehta (ed.), pp. 541-557, American Geophysical Union, Washington, D. C.

Onishi Y and DS Trent. 1992. “Turbulence Modeling for Deep Ocean Radionuclide." International Journal for Numerical Methods in Fluids 15(9):1059-1071. 